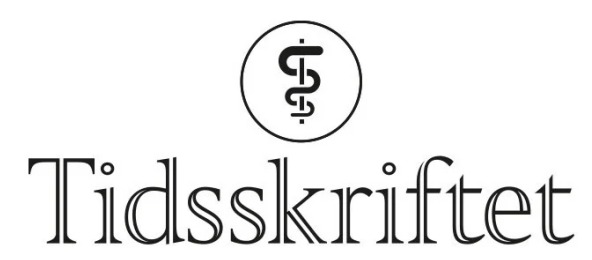

DEN NORSKE LEGEFORENING

\title{
Hva er likhet?
}

\author{
LEGELIVET
}

BERIT BRINGEDAL

berit.bringedal@legeforeningen.no

LEFO - Legeforskningsinstituttet

\section{Covid-19 har på nytt aktualisert spørsmålet om hva likebehandling i helsetjenesten egentlig betyr.}

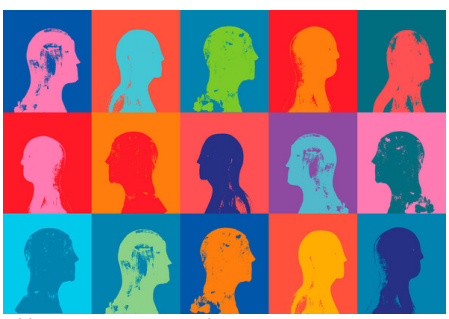

Illustrasjon: Sloop

communications / iStock

Likebehandling er en sentral målsetning for helsetjenesten, men samtidig er den kronisk underpresisert. Hva innebærer likebehandling i praksis? Lik tilgang, lik medisinsk

behandling, like muligheter for helseforbedring eller helbredelse, like mange leveår, eller like mange kvalitativt gode leveår?

Spørsmålet om likebehandling av covid-19-pasienter med behov for intensiv pleie har vært aktuelt i vår. Italienske retningslinjer ble verdenskjente fordi høy alder var et selvstendig nedprioriteringskriterium. De britiske retningslinjene fra National Institute for Health and Care Excellence (NICE) sier at respiratorer skal fordeles likt mellom alle pasienter, etter at det er gjort en vurdering av pasientens skrøpelighet (1), samtidig som det eksplisitt sies at alder alene ikke er et kriterium. Det foreligger ikke norske retningslinjer for fordeling av respiratorer, men Helsedirektoratet og spesialistforeningene i Legeforeningen har gitt generelle retningslinjer for prioriteringer under pandemien. Norsk geriatrisk forening foreslår noe av det samme som NICE, med særlig henvisning til at svært syke gamle har liten nytte av intensivbehandling, men desto større nytte av god palliasjon (2).

Julian Savulescu og kolleger har sett på NICE sine retningslinjer og kritiserer dem for å være «et ustabilt kompromiss mellom egalitarisme og utilitarisme» (3). Egalitarismen uttrykkes ved at alle skal ha like stor sjanse for å få respiratorbehandling. Samtidig skal sannsynligheten for effekt av behandlingen tillegges vekt - som er et utilitaristisk prinsipp, fordi det tar hensyn til helsegevinsten som kan realiseres. Likebehandlingsprinsippet støter altså mot kravet om at respiratorene skal fordeles slik at effekten blir størst mulig. 
Savulescu og kolleger har ingenting imot dette. Tvert imot hevder de at sannsynligheten for effekt ikke er tilstrekkelig, man må også ta hensyn til hvor mange friske leveår som kan forventes av behandlingen. Effekt må med rimelighet defineres som en kombinasjon av den umiddelbare helseforbedringen og varigheten av den. NICE-retningslinjene sier at effekt skal vektlegges, men ikke pasientens alder, hvilket innebærer at varigheten av effekten ikke skal telle.

\section{«Det er ikke åpenbart at dette er brudd på likhetsprinsippet, det kommer an på hvilken likhetsdefinisjon man legger til grunn»}

Savulescu definerer egalitarisme som at alle skal ha like muligheter til respiratorbehandling, uavhengig av andre faktorer, mens utilitarisme er å maksimere antall forventete (gode) leveår i befolkningen. En utilitarist vil dermed prioritere unge foran eldre, dersom den unge med sannsynlighet kan forventes å oppnå flere leveår med behandlingen.

Det er ikke åpenbart at dette er brudd på likhetsprinsippet, det kommer an på hvilken likhetsdefinisjon man legger til grunn. Dersom målet er mest mulig likhet i antall leveår over et livsløp, vil likebehandling innebære å prioritere i henhold til antall leveår den enkelte kan få som resultat av behandlingen. Generelt vil det bety at unge prioriteres foran eldre, fordi potensialet for fremtidige leveår øker med minkende alder.

I bioetikken mener mange at det er en nødvendig motsetning mellom prinsippet om likebehandling på den ene siden og mest mulig helseforbedring på den andre. Motsetningen gjelder imidlertid bare for bestemte definisjoner av likhet (4). Diskusjonen om prioritering mellom covid-19-pasienter har tydeliggjort behovet for mer presise definisjoner av målsetningene og økt bevissthet om hvilke målsetninger som kan komme i konflikt med hverandre.

\section{LITTERATUR}

1. COVID-19 rapid guideline: critical care in adults. NICE guideline [NG159]. https://www.nice.org.uk/guidance/ng159 Lest 10.7.2020.

2. Råd og prioriteringer fra Norsk forening for geriatri. https://www.legeforeningen.no/contentassets/2C35c183aogo430e938coc625501fo5a/norsk-forening-forgeriatri-12.pdf Lest 10.7.2020.

3. Savulescu J, Cameron J, Wilkinson D. Equality or utility? Ethics and law of rationing ventilators. Br J Anaesth 2020; 125: 10-5. [PubMed][CrossRef]

4. Sen A. Inequality reexamined. Cambridge: Harvard Uni Press, 1992.

Publisert: 24. august 2020. Tidsskr Nor Legeforen. DOI: 10.4045/tidsskr.20.0543

(C) Tidsskrift for Den norske legeforening 2023. Lastet ned fra tidsskriftet.no 26. april 2023. 